\title{
Effect of Lead Toxicity on the Structure and Function of Organs in Rats
}

\author{
MIHAI MITULETU1', MARIOARA NICOLETA FILIMON2*, DALIBORCA CRISTIANA VLAD ${ }^{1,3}$, ADINELA CIMPORESCU1,3, \\ EUGENIA DUMITRESCU ${ }^{4}$, GABI DUMITRESCU ${ }^{4}$, CRISTIAN NICA ${ }^{5 *}$, ADRIAN SINITEAN ${ }^{2}$, DOINA VERDES ${ }^{2 *}$ \\ 'University of Medicine and Pharmacy Victor Babes, Faculty of Medicine, 2 Eftimie Murgu, 300041, Timisoara, Romania \\ ${ }^{2}$ West University of Timisoara, Faculty of Chemistry, Biology, Geography, Biology-Chemistry Department, 16 Pestalozzi, 300115, \\ Timisoara, Romania \\ 3Pius Brinzeu Emergency Clinical County Hospital,Toxicology Department, 156 Liviu Rebreanu Blvd., 300723, Timisoara, Romania \\ “Banat's University of Agriculture and Veterinary Medicine King Michael I of Romania,119 Calea Aradului, 300645, Timisoara, \\ Romania \\ ${ }^{5}$ Victor Babes University of Medicine and Pharmacy, Faculty of Medicine, 2 Eftimie Murgu Sq., 300041, Timisoara, Romania
}

\begin{abstract}
Acute and chronic exposure to lead induces oxidative damage and morphologic and physiological changes in tissues and organs. The aims of this study were to determine the concentration of heavy metals like $\mathrm{Zn}$, $\mathrm{Al}, \mathrm{Li}, \mathrm{Cu}$ and $\mathrm{Pb}$ in different organs and to identify histopathological changes in the liver and kidneys of laboratory animals in case of chronic lead intoxication. In most cases, the heavy metal concentrations analyzed in the control group organs are significantly lower than the values determined in the organs in the experimental groups. High Pb concentration caused increased liver and kidney damage.
\end{abstract}

Keywords: heavy metals, lead, kidney, liver

Lead is one of the four metals with the most distructive effecton human and animal health [1]. As a result of acute or chronical exposure of the human or animal body to industrial and environmental pollution with lead causes the appearance of biochemical, physiological and behavioral changes[2,3]. Lead poisoning sources in animals and humans may be foods and beverages witch can contain significant amounts of this heavy metal. Healthy organisms are capable to bind, neutralize and eliminate small amounts of lead. If the quantity accumulated in the organism is too high, the elimination capacity is reduced and therefore the number of free radicals will increase [4]. When lead penetrates into the body, it is absorbed by erythrocytes, kidneys, bone and nervous tissue. Lead can induce oxidative damage to membranes, through the accumulation of metabolites or oxidant substances such as iron ions. By direct or indirect inhibition of antioxidant enzymes, total cellular antioxidant protection is reduced[5]. This affects the function and structure of the membrane, resulting in changes in the physiological processes of organs and tissues[ 6 ]. The aims of this study were to determine the concentration of heavy metals: Zinc (Zn), Aluminum(Al), Lithium (Li), Copper (Cu), and Lead $(\mathrm{Pb})$ in different organs and to identify histopathological changes in the liver and kidneys of laboratory animals in case of chronic lead intoxication.

\section{Experimental part}

Animal study: Adult Sprague-Dowley female rats were obtained from the Experimental Animal Center of Faculty of Veterinary Medicine Timisoara. The animals consulting and complying the conditions imposed by the Ethical Commission approval according to the European Union's Directive (2010)/63/EU for animal experimentation [7]. The tested toxic agent was administered as $\mathrm{Pb}$ acetate in drinking water for 6 months. The rats were split into 4 groups: group A ( 10 rats were the control group, which did not receive $\mathrm{Pb}$ ), group $\mathrm{B}$ (10 rats which received $\mathrm{Pb}$ at a dose of 50ppm), group $\mathrm{C}$ ( 10 rats which received $\mathrm{Pb}$ at a dose of100 ppm), group D (10 rats which received $\mathrm{Pb}$ at a dose of $150 \mathrm{ppm}$ ). The dose of $50 \mathrm{ppm} / \mathrm{L}$ water, represents the maximum admissible limit.
Chemical analysis: Chemical analyses to determine heavy metal contents were carried out for the organs of interest (liver, kidney, lung, spleen) from the animals in each experimental lot. $3 \mathrm{~g}$ of tissue samples were ovendried at $105^{\circ} \mathrm{C}$ for 48 hours. Subsequently, the samples were digested in the calcination furnace. The ash obtained was dissolved with $20 \mathrm{ml}$ of $0.5 \mathrm{~N} \mathrm{HNO} 3$ solution and filtered, and then analyzed. Digestion was performed with $0.5 \mathrm{~N}$ $\mathrm{HNO} 3$ solutions. The concentrations of zinc ( $\mathrm{Zn}$ ), aluminum (Al), lithium ( $\mathrm{Li})$, copper (Cu), and lead (Pb) of the obtained solutions were determined using a high resolution continuous flame atomic absorption spectrophotometer (ContrAA 300, Germany).

Histological analysis: The biological samples of liver and kidneywere fixed in $10 \%$ neutral formalin buffer, dehydrated in ascending grades of ethanol,clarified in xylene, embedded in paraffin and cut into $5 \mu \mathrm{m}$ thick sections. For overall diagnosis of each case the Masson Trichrome staining was performed [8]. For the kidney tissue, the Hematoxiline-Eosine stain was used (HE)[9-11]. Histological sections were examined under a Nikon Eclipse TE2000-U microscope.

Statistical analysis:The obtained values for heavy metal concentrations in the organs of interest were expressed as mean \pm standard deviation. Data were analysed using variance analysis. The difference significance between samples was determined using Mann-Whitney tests. The difference was considered significant when $0.001 \leq p<$ 0.05 , highly significant when $p<0.001$ and non-significant when $p>0.05$, where $p$ is the level of significance.

\section{Results and discutions}

The results of chemical analyses on the concentration of heavy metals: $\mathrm{Zn}, \mathrm{Al}$, Li, Cu, Pb in the organs: liver, kidney, lung, spleen is shown in table 1 as mean \pm SD.

In most cases, the concentrations of the metal analyzed in the control group organs are significantly lower than the values determined in the organs in the experimental groups, except $\mathrm{Zn}$ concentrations in the liver and lung for the $B$ group, the Zn concentration in the kidneys for the batches $C$ and $D$. The $Z n$ concentration in the organs of laboratory animals in the experimental groups shows increases: lung $<$ spinal cord <liver < liver. The Al concentration in the lung

\footnotetext{
* email: marioara.filimon@e-uvt.ro; dverdes@umft.ro; nica.cristian.m@gmail.com
} 


\begin{tabular}{|c|c|c|c|c|c|c|}
\hline & \multicolumn{6}{|c|}{ Heavy metals } \\
\hline Variants & Organ & $\mathbf{Z n}$ & Al & $\mathbf{L i}$ & $\mathrm{Cu}$ & $\mathrm{Pb}$ \\
\hline \multirow[t]{4}{*}{ Group A (Control) } & liver & $40.88 \pm 0.97$ & $11.87 \pm 0.23$ & $126.64 \pm 0.75$ & $110.81 \pm 0.41$ & $0.86 \pm 0.01$ \\
\hline & kidney & $40.90 \pm 0.75$ & $70.99 \pm 0.35$ & $65.53 \pm 0.57$ & $92.83 \pm 0.35$ & $0.80 \pm 0.01$ \\
\hline & lung & $41.41 \pm 0.59$ & $323.03 \pm 2.54$ & $756.38 \pm 0.97$ & $165.45 \pm 0.61$ & $4.98 \pm 0.05$ \\
\hline & spleen & $30.64 \pm 0.89$ & $103.64 \pm 0.79$ & $157.71 \pm 0.07$ & $126.17 \pm 0.20$ & $5.37 \pm 0.32$ \\
\hline \multirow{4}{*}{$\begin{array}{l}\text { Group B } \\
\text { (50 ppm Pb) }\end{array}$} & liver & $18.26 \pm 0.93^{* *}$ & $81.29 \pm 0.53^{* 8}$ & $190.86 \pm 0.17^{* *}$ & $3.53 \pm 0.07^{* *}$ & $3.44 \pm 0.24^{* *}$ \\
\hline & kidney & $107.13 \pm 1.00^{* *}$ & $304.39 \pm 1.14^{* *}$ & $824.82 \pm 0.75^{* *}$ & $324.03 \pm 0.40^{* *}$ & $2.46 \pm 0.12^{* *}$ \\
\hline & lung & $34.12 \pm 0.96^{* *}$ & $41.62 \pm 0.87^{* *}$ & $348.16 \pm 0.37^{* *}$ & $94.61 \pm 0.12^{* *}$ & $4.58 \pm 0.21^{*}$ \\
\hline & spleen & $52.74 \pm 0.87^{* *}$ & $1305.14 \pm 1.53^{* *}$ & $588.23 \pm 0.35^{* *}$ & $110.29 \pm 0.95^{* *}$ & $5.16 \pm 0.17$ \\
\hline \multirow{4}{*}{$\begin{array}{l}\text { Group C } \\
(100 \mathrm{ppm} \mathrm{Pb})\end{array}$} & liver & $74.41 \pm 0.95^{* *}$ & $114.35 \pm 1.17^{* *}$ & $44.26 \pm 0.07^{* *}$ & $11.066 \pm 0.21^{* *}$ & $6.88 \pm 0.21^{* *}$ \\
\hline & kidney & $32.23 \pm 0.86^{* *}$ & $302.57 \pm 0.95^{* *}$ & $242.05 \pm 0.45^{* *}$ & $211.8 \pm 0.57^{* 8}$ & $4.59 \pm 0.10^{* *}$ \\
\hline & lung & $45.31 \pm 0.89 * *$ & $51.25 \pm 0.56^{* *}$ & $353.21 \pm 0.42^{* *}$ & $96.25 \pm 0.36^{* *}$ & $4.76 \pm 0.13^{*}$ \\
\hline & spleen & $60.00 \pm 1.12^{* *}$ & $265.73 \pm 0.95^{* *}$ & $648.38 \pm 0.84^{* *}$ & $722.78 \pm 1.24^{* *}$ & $5.96 \pm 0.11^{*}$ \\
\hline \multirow{4}{*}{$\begin{array}{l}\text { Group D } \\
(150 \mathrm{ppm} \mathrm{Pb})\end{array}$} & liver & $354.75 \pm 0.93^{* *}$ & $112.99 \pm 0.79^{* *}$ & $51.36 \pm 0.07 * *$ & $47.93 \pm 0.87^{* *}$ & $4.72 \pm 0.13^{* *}$ \\
\hline & kidney & $31.78 \pm 0.93^{* *}$ & $211.28 \pm 0.85^{* *}$ & $368.51 \pm 0.75^{* *}$ & $240.76 \pm 1.10^{* *}$ & $4.73 \pm 0.15^{* *}$ \\
\hline & lung & $51.45 \pm 0.75^{* *}$ & $52.34 \pm 0.53^{* *}$ & $354.75 \pm 0.89^{* *}$ & $97.55 \pm 0.75^{* *}$ & $4.30 \pm 0.10^{* *}$ \\
\hline & spleen & $73.24 \pm 0.79 * *$ & $268.21 \pm 0.78^{* *}$ & $651.35 \pm 0.98^{* *}$ & $723.79 \pm 2.53^{* *}$ & $6.75 \pm 0.17^{* *}$ \\
\hline
\end{tabular}

Table 1

CONCENTRATION OF HEAVY METALSIN TISSUES

Data are expressed as mean \pm SE. Number of sample in each group is 10. Group A = Martor (Control), Group B(50 ppm Pb), Group $C(100$ ppm Pb), Group D (150 ppm Pb) = Treated group with acetate de Pb, Significant change in comparison between groups: ** Highly significant $(P \leq 0.001) *$ Significant $(0.001 \pm P \leq 0.05)$ N.S Non significant $(P>0.05)$

for groups $B, C$ and $D$ shows significant decrease compared to the control. In the organs of interest, the Al concentration shows increases as follows:lung <liver <spleen $<$ kidneys.Li liver concentration for groups C and D vs. control shows significant decreases; a similar situation for the Li concentration in the lung in the same experimental lots. The concentration of $\mathrm{Li}$ increases in the organs of interest as follows: liver <kidney <spleen.The concentration of $\mathrm{Cu}$ in the liver and lung in the $B, C$ and $D$ rat groups shows significant decrease compared to the control group values. Cu concentration in the spleen shows decrese, only in the B-group animals. These significant decreases are maintained in relation to the values for the control group. The concentration of $\mathrm{Cu}$ in the organs of interest shows increases as follows: liver < kidney < spleen. For the concentration of $\mathrm{Pb}$ in the lung of the animals in $\mathrm{B}$, $C$ and $D$, there are statistically significant decreases from the determined concentrations in the animals in the control group. In the case of spleen $\mathrm{Pb}$ concentration for group $\mathrm{B}$ versus control group, the decrease was insignificant $(p=$ 0.231 ). In cases of intoxication, excess $\mathrm{Pb}$ accumulation in the organs of interest shows an increase in $\mathrm{Pb}$ concentration as follows: lung kidney < spleen.

The organs of interest (liver and kidney) taken from animals of the 4 experimental groups were stained and examined microscopically to identify any morphopathological changes. To assess morphological alterations of the kidney we performed Masson trichrome stain, which turns the cytoplasm of the kidney cell red and collagen fibers and cell nuclei blue. The control group did notreport pathological changes of renal tissue (fig. 1). The group of animals treated with lead concentration of $50 \mathrm{ppm}$, did not show alterations in kidney tissue compared with controls. Compared with the control group, the animals

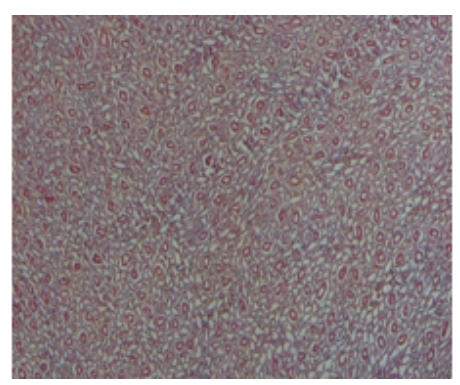

Fig. 1. Kidney tissue control lot; Masson trichrome staining. X100

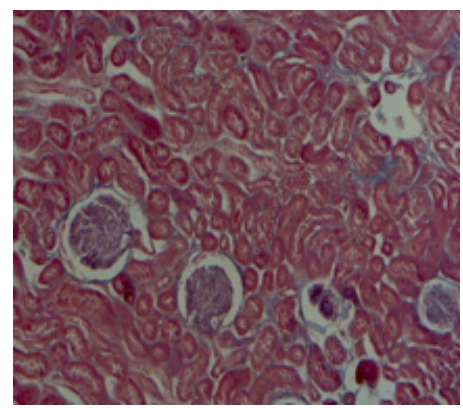

Fig. 2. Renal tissue. Masson trichrome staining, lot 100 ppm, X200

that had received higher doses of lead (100 ppm and 150 $\mathrm{ppm}$ ), showed changes in the renal tubules, as well as in the glomerulus. Administration of lead in concentration of $100 \mathrm{ppm}$ induced tubular changes: tubules nucleus pyknosis, focal tubular degeneration with cytoplasmic vacuolation, focal necrosis. Regarding the glomeruli, we identified zonal mesangial proliferation and slight thickening of the glomerular basement membrane (fig. 2). On the tissue sections belonging to the group treated with a dose of $150 \mathrm{ppm}$ lead, we reported: renal tubular epithelium degeneration and focal tubular necrosis, renal interstitium edema and extravasated red blood cells, glomerular basement membrane thickening and 
degenerative lesions replaced by fibrosis with collagen fibers arranged or peritubal-periglomerular and interstitial lymphocytic inflammatory infiltrate (fig. 3-5). On HE stained liver sections from animals in the control group and the group treated with $50 \mathrm{ppm} \mathrm{Pb}$, microscopy revealed single or polinucelate polygonal hepatocytes arranged in cords and radial oriented towards end-stage liver venula (fig. 6).

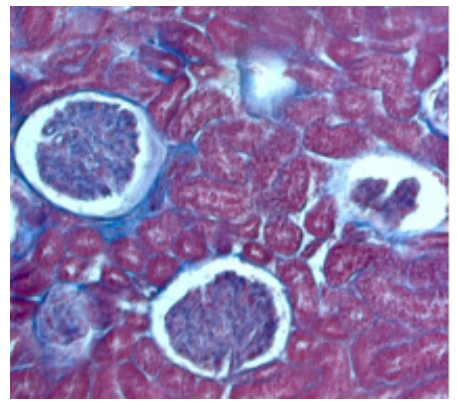

Fig. 3. Renal tissue. Masson trichrome staining, lot 150 ppm, X200.

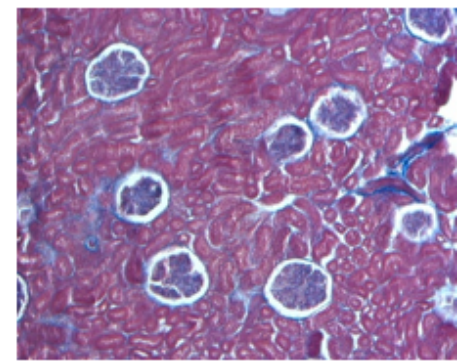

Fig. 4. Renal tissue. Masson trichrome staining, lot 150 ppm, X400

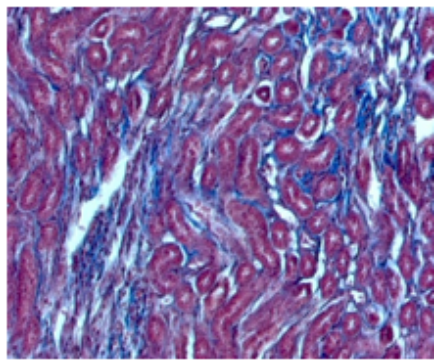

Fig. 5. Renal tissue. Masson trichrome staining, lot 150 ppm, X400

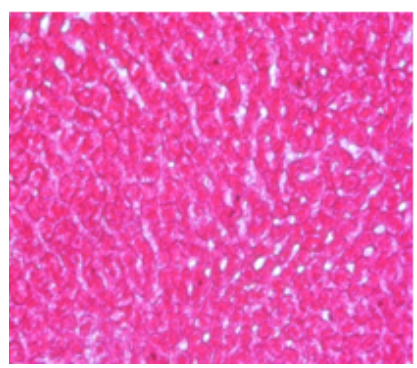

Fig. 6. Hepatic tissue, lot 50ppm. HE staining; X100

On the animals in the experimental group treated with higher doses of lead (100 ppm, $150 \mathrm{ppm})$ we noted alterations of liver parenchyma with varying degrees of vacuolar alteration of hepatocytes, redness and swelling of the sinusoids (fig. 7), its type and fibrosis peliozisvenulei end-stage liver (fig. 8).

Regarding the distribution of lead in different organs, studies have shown that this process takes place in several phases, namely: in the first stage the toxic accumulates in the liver [12], histiocitar system and kidneys[13]; the lead

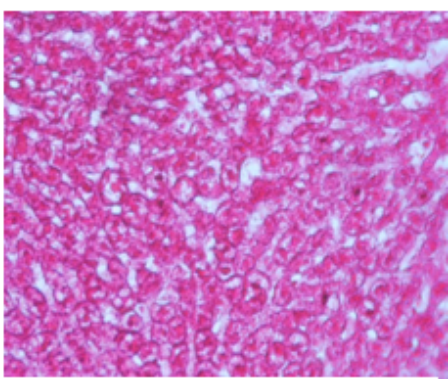

Fig. 7. Hepatic tissue. HE staining, lot 150 ppm, x 200

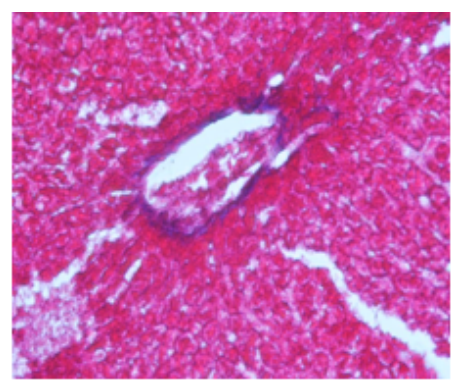

Fig. 8. Hepatic tissue. HE staining, lot $150 \mathrm{ppm}, \times 200$

that was not excreted is fixed in the bone tissue in the second phase[14]. The highest sensitivity to heavy metal toxicity can be observed in the nervous system, butalso in the cardiovascular system, gastrointestinal tract, kidneys, and the hematopoietic system [15-17]. There are studies in the literature regarding heavy metal accumulation in liver and kidney tissues. In case of heavy metal intoxication, their concentration is determined in these two organs to assess the level of contamination. Such studies have been conducted on fish [18-21]. Heavy metal accumulation in kidneys and liver is not random due to the role of these two organs in the detoxification of the organism [18,22]. High concentrations of Pb in the organs of the reproductive system was also reported in the studies performed on a batch of male rats where $\mathrm{Pb}$ poisoning also caused histopathological changes at the testicular level with varying degrees of damage to the seminiferous tubules and binucleated giant cells were also encountered in a few seminiferous tubules [23]. Also, structural changes correlated with the level of exposure in the ovaries, uterus, and fallopian tubes were shown. They were mainly edemas and necrosis, denudation, and/or different stages of follicle evolution. These alterations have been shown to indicate infertility in female rats [24]. In the literature, various liver and kidney lesions in murine experimental models exposed to heavy metal toxicity were reported. Studies related to lead intoxication on hepatotoxicity have described morphological, tissue and cellular changes: dysplastic hepatic epithelial cells, necrotic lesions and portal inflamatory infiltrate of variable intensity (mild, moderate, and intense) [25].Mehana et al (2012), in a study on Sprague-Dowley rats exposed to different doses of lead acetate have shown histological lesions similar to the control group. The study identified lobular inflammatory lesions and steatosis, cell death by apoptosis and necrosis. In the portal areas were observed perivascular edema and congestion, portal fibrosis and hyperplasic lesions in the bile ducts [26]. Similar results have been reported by other studies $[27,1,28]$.On the other hand, other studies on the effect of lead on rat liver tissue have revealed, in addition to the above, degenerative lesions represented by the disorganization of hepatic lobular architecture, intracytoplasmic vacuolization and hepatocyte degeneration $[29,23]$. Our study has shown tubular and glomerular lesions in animals exposed to increased doses of lead compared to the control group and the ones exposed to low doses. Studies in the literature regarding lead poisoning in laboratory animals reported morphophysiological changes in the kidney. Navarro-Moreno etal. (2009) [3] revealed structural, ultrastructural and functional changes in renal epithelial cells. Following lead acetate administration in Wistar rats, phenotypic changes were observed in the cell membrane marked by the disappearance of microvilli and the development of jonctional complexes at the cellular apical pole. This causes decreased absorption capacity and implicitly impaired renal function. Other studies on $\mathrm{Pb}$ poisoning in 
rats indicate the following histopathological changes in the kidney: necrosis and inflammatory interstitial, glomerular and tubular infiltration. Epithelial cells in the proximal tubules showed pathognomonic intranuclear inclusions, as well as the increase in nuclear volume[23].

\section{Conclusions}

Lead intoxications induce modifications in the concentration of other heavy metals in the organism (mineral imbalances) but also histopathological changes in liver and kidney. High $\mathrm{Pb}$ concentration in case of intoxication causes increased liver and kidney damage.

\section{References}

1.KHAN M.S.H., MOSTAFA M.S., HOSSAIN M.A., SAYED M.A., Bang J Vet Med., 6, no. 2, 2008, p. 203-210.

2.COURTOIS E., MARQUES M., BARRIENTOS A., J Am Soc Nephrol, 14,2003, p. $1464-70$

3.NAVARRO-MORENO L.G., QUINTANAR-ESCORZA M.A., GONZALEZ S., CALDERÓN-SALINASJ.V., Toxicology in Vitro, 23, no.7, 2009, p.1298304

4.BORDEAN D.M., GOIAN M., Cercetãri cu privire la acumularea unor metale grele în organism si principalele metode de detoxifiere, Editura Eurobit, Timisoara, 2010

5.HSU P.C., GUO Y.L., Toxicology, 180, no. 1, 2002,p. 33-44

6.RENDON-RAMIREZA., CERBON-SOLORZANO J ., MALDONADO-VEGA M., QUINTANAR-ESCORZA M.A., CALDERON-SALINAS J.V., Toxicol In Vitro, 21, 2007, p.1121-112 6

7.*** European Commission (2010). Directive 2010/63/EU of the European Parliament and the Council of 22 September 2010 on the protection of animals used for scientific purposes. Brussels,Belgium: European Commission.

8.BANCROFT, J.D., STEVENS, A., Theory and Practice of Histological Techniques. $4^{\text {th }}$ ed. Churchill-Livingstone, New York,1996

9.PUSCASIU D.,TATU C., TATU R.F., POTENCZ E., POPESCU R.,MUNTEAN I., VERDES D., Romanian Journal of Morphology and Embryology, 52, 2011, p. 369-372

10.DUMITRESCU, G., PETCULESCU CIOCHINA, L., STANA, L., CREESCU, I., POPESCU, R., FILIMON, M.N., VOIA, O.S., Romanian Biotehnological Letters, 19, no. 1, 2014, p. 8925-8934
11.DUMITRESCU, G., PET, I., DRONCA, D., AHMADI, M., PETCULESCU, CIOCHINA, L., FILIMON, M.N., POPESCU, R., Rev.Chim.(Bucharest), 69, no. 1, 2018, p. 140-143

12.PATRA R.C.,SWARUPD.,DWIVEDI S.K., Toxicology, 162,no.2,2001, p.81-88

13.KUMAR, P., PRASAD, Y., PATRA, A.K., Bull Environ Contam Toxicol, 79, 2007, p.396

14.MALDONADO-VEGA, M., CERBÓN-SOLÓRZANO, J., CALDERÓNSALINAS, J.V., Human \& Experimental Toxicology, 21, 2002, p.409-414 15.PATRICK L., Altern Med Rev, 11, no.1, 2006, p.2-22

16.PROZIALECKW.C., EDWARDSJ.R., NEBERTD.W., WOODSJ.M., BARCHOWSKYA.\&ATCHISONW.D., Toxicol Sci, 102, 2008, p. 201-21

17.OZTURK M., OZOZEN G., MINARECI O., MINARECI E., Iranian J Environ Health Sci Eng, 6, no.2, 2009, p.73-80

18.KOJADINOVIC J., PATIER M., LE CORRE M.,Environ. Poll., 146, 2007, p.548-566

19.PERCIN F., SOGUT O.J. Anim. Vet. Adv., 2010, 9, no.21, p.2768-2773 20.VIZZINI S., TRAMATI C., MAZZOLAA.,Chemosphere, 78, 2010, p.12361243

21.SOGUT 0., PERCIN F., African J ournal of Biotechnology, 10, no.7, 2011,p.1252-1259

22.IMANPOUR NAMIN I ., MOHAMMADIN M., HEYDARI S., MONSEF RAD F., Caspian. J. Env. Sci., 9, no.1,2011, p.1-8

23.EL-NEWESHY, M., EL-SAYED, Y.,Experimental Toxicology and Pathology, 63,2011, p.221-227

24.DUMITRESCU E., CHIURCIU V., MUSELIN F., POPESCU R., BREZOVAN

D., CRISTINA R.T., Turk J Biol, 39,2015, p.284-289

25.ABDEL MONEIM AE., OTHMAN M.S., MOHMOUD S.M., EL-DEIB K.M., 2013, Toxicology Mechanisms and Methods,23, no.8, p.624-633

26.MEHANA E.E., MEKI A.R., FAZILI K.M., Experimental and Toxicologic Pathology, 64, 2012,p.291-295

27.BADIEI K., MOSTAGHNI A., NOWROOZIASL A., TABATABAEL N., Pak Vet J., 26, no.4, 2006, p. 184-186

28.SHAIMA A., SAFER A., AFZAI M., MOUSA S., J Toxicol Sci., 34, no.1, 2009,p.77-87

29.SHALAN M.G., MOSTAFAM.S.,HASSOUNAM.M.,HASSABELNABIS.E.,EL-REFAIEA., Toxicology, 206, no.1, 2005, p.1-15

Manuscript received: 19.11 .2018 